\title{
Comparative Assessment of Splash Erosion Measuring Devices in Auchi Polytechnic, Auchi, Edo State
}

\author{
Edeki Ahanmisi Ibhanesebhor M. E. Ighomaro M. Oremegue O. \\ Department of Agricultural and Bio-Environmental Engineering Technology, \\ Auchi Polytechnic, Auchi, Edo State, Nigeria
}

\begin{abstract}
Soil erosion is recognized as a global threat against the sustainability of the natural ecosystem and the environment because of its severe effects in agricultural productivity, damage to infrastructure and pollution of water bodies. This study aims to compare the splash erosion on open field using Morgan and splash board method. The fabrication of the splash cups and splash board was carried based on the principles of the already existing devices in literature and in the department of Agricultural and Bio-Environmental Engineering Technology Auchi Polytechnic Auchi. The rainstorm depth ranged from 7 to $81 \mathrm{~mm}$ and the computed KE obtained ranged from 294 to $3233.4 \mathrm{~J} / \mathrm{m}^{2}$. A total of 15 rainfall events were used in the season. For site A the amount of soil splashed per rainfall event ranged from $0.02 \mathrm{~g} / \mathrm{m}^{2}$ to $4.77 \mathrm{~g} / \mathrm{m}^{2}$ and zero (no splash) to $2.39 \mathrm{~g} / \mathrm{m}^{2}$ for Morgan cup and Splash board device respectively. Studies of splash erosion on cultivated land should be made to determine the effect of cultivation on the soil in the area.
\end{abstract}

Keywords: Morgan's Splash cup, splash board, kinetic energy, soil erosion, splash erosion, rainstorm

DOI: $10.7176 / \mathrm{JEES} / 11-4-06$

Publication date: April $30^{\text {th }} 2021$

\subsection{INTRODUCTION}

Soil erosion is recognized as a global threat against the sustainability of the natural ecosystem and the environment because of its severe effects in agricultural productivity, damage to infrastructure and pollution of water bodies. Adverse impacts due to human activities resulting in accelerated soil erosion process have been well documented (Morgan, 1995). It is also noteworthy that much more attention has been given to study the mechanisms associated with the process of soil erosion in the second half of the 20th century. Land degradation and related processes such as gullying, flooding and sedimentation, are global phenomena (Salama et al., 2008). They have been recognised as a major threat to the global environment: it impacts directly human health and livelihoods (Vogt et al., 2011). The ratification of the United Nations Convention to Combat Desertification (UNCCD) by 193 affected nations shows its widespread effects (Vogt et al., 2011). Soil erosion is the main form of land degradation: a threat that has destroyed nearly one-third of land suitable for agriculture since the 1950s (Pimentel et al., 1995). Moreover, the economic consequences of these processes are more severe in developing countries, which lack resources for prevention and mitigation (Tamene and Vlek, 2008).

Splash erosion is a prime cause of all erosion, erosions that develop into gullies begins as small craters formed by rain drops (Mekonnen et al., 2013), rendering an increasingly large area unsuitable for grazing and agriculture and leading to reservoir sedimentation (Gebreyohannis, 2009), threatening livelihoods. To protect livelihoods, cost-effective measures to prevent and mitigate gully erosion should be put in place. This requires both an intimate knowledge of gully erosion processes (Daba et al., 2003 and Poesen, 2011) and gully growth rates (Daba et al., 2003).

When a raindrop or group of raindrops with sufficient kinetic energy hits soil surface, soil particles are detached from their original position. The particles detached through this process are generally transported by two mechanisms: displacement by the impact of the falling raindrop and entrainment by overland or sheet flow (Lal, 1990). This process of soil erosion is known as splash erosion.

The kinetic energy carried by a raindrop is a strong detaching agent and influences soil erosion process by breaking the clods and soil aggregates into individual particles and displacing them from their original position. Turbulence produced by the impact may also accelerate the erosion process in presence of shallow overland flow. Soil moisture content, particle size distribution, soil structure and content of organic matter influence the amount of splash erosion. The presence of overland flow greatly influences the extent of splash erosion. When flow is developed over the soil surface, Rainfall particles can either be washed away by overland flow as sheet erosion or more concentrated flows can cause rill erosion (Tameni and Vlek, 2008).

Residents in Auchi have complained over the years that recent gully formation is taking away grazing land, threatening their livelihood, whole shops around Igbe road and other areas have been taken over by water due to erosion. It is however unclear how the mechanics behind low-land erosion formation have changed over the past decade to account for the increase in denudation. Since no research has been carried out on the root cause of the erosion in this area, nor have the lands been mapped and measured, soil erosion can be averted by means of preserving a protective cover on the soil, creating a barrier to the erosive agent, and enhancing the landscape to 
manipulate runoff amounts and rates. There are numerous treatments, mixtures of treatments, and rising techniques that might also be appropriate for the web page of erosion. The result of this study will help engineers, scientists, coverage makers and the widespread public on the manage measures appropriate for raindrop erosion eradication (Fan and Li, 1993, Igwe, 2012).

The prevention of soil erosion is a vital environmental difficulty that desires urgent attention. Comparison of the splash erosion the usage of Morgan and Splash board approach would expose and limit the price of soil loss in the learn about area. The factors influencing the price of splash erosion motion would additionally be determined the use of Morgan and Splash board method. Since erosion is pushed with the aid of the power derived from raindrops impacting the soil surface, comparability of splash erosion the usage of Morgan and splash board would additionally show how raindrop electricity overcome the bonds that preserve soil particles in loamy, silt and sandy soils (Fan and Li, 1993). Assessment and comparison of splash soil the use of Morgan and Splash board technique would determine the accurate technique of finding out splash soil in Auchi, Edo State. Therefore, it is necessary to curb the rate of splash erosion that leads to serious runoff and soil loss in the learn about area. This study aims to compare the splash erosion on open field using Morgan and splash board method. This study planned to compare splash erosion measuring devices, two devices will be constructed and used for this study which are: Morgan's splash cup and splash board method in an open space using field measurement.

\subsection{MATERIALS AND METHODS}

\subsection{Description of the Study Area}

Auchi Polytechnic is located between latitude $6^{0} 70^{\prime \prime} 00$ " to $7^{0} 18^{\prime \prime} 00^{\prime}$ North of the Equator and longitude $6^{0}$ 49"00" East of the Greenwich Meridian. Auchi is the headquarters of Etsako-West Local Government Area of Edo State, Nigeria. The area covers a total land area of $94,562 \mathrm{~km}^{2}$. Auchi is underlain by sedimentary formation of the Miocene-Pleistocene age (Odemerho and Onokherhoraye, 1985). The area is found in the South Central (lower Niger sedimentary rock areas). The sedimentary rocks in the area are easily broken down by the incidence of water which results in the removal of particles of the rock. Auchi area is generally sloppy and as a result, the topography allows the easy movement of soil particles such that with little rainfall, rapid movement of materials is encouraged. Auchi area is referred to as the "Oshibujie" plain and it is surrounded by the Kuruku hills up North and Samorika hills with a height of about 672 meters above mean sea level.

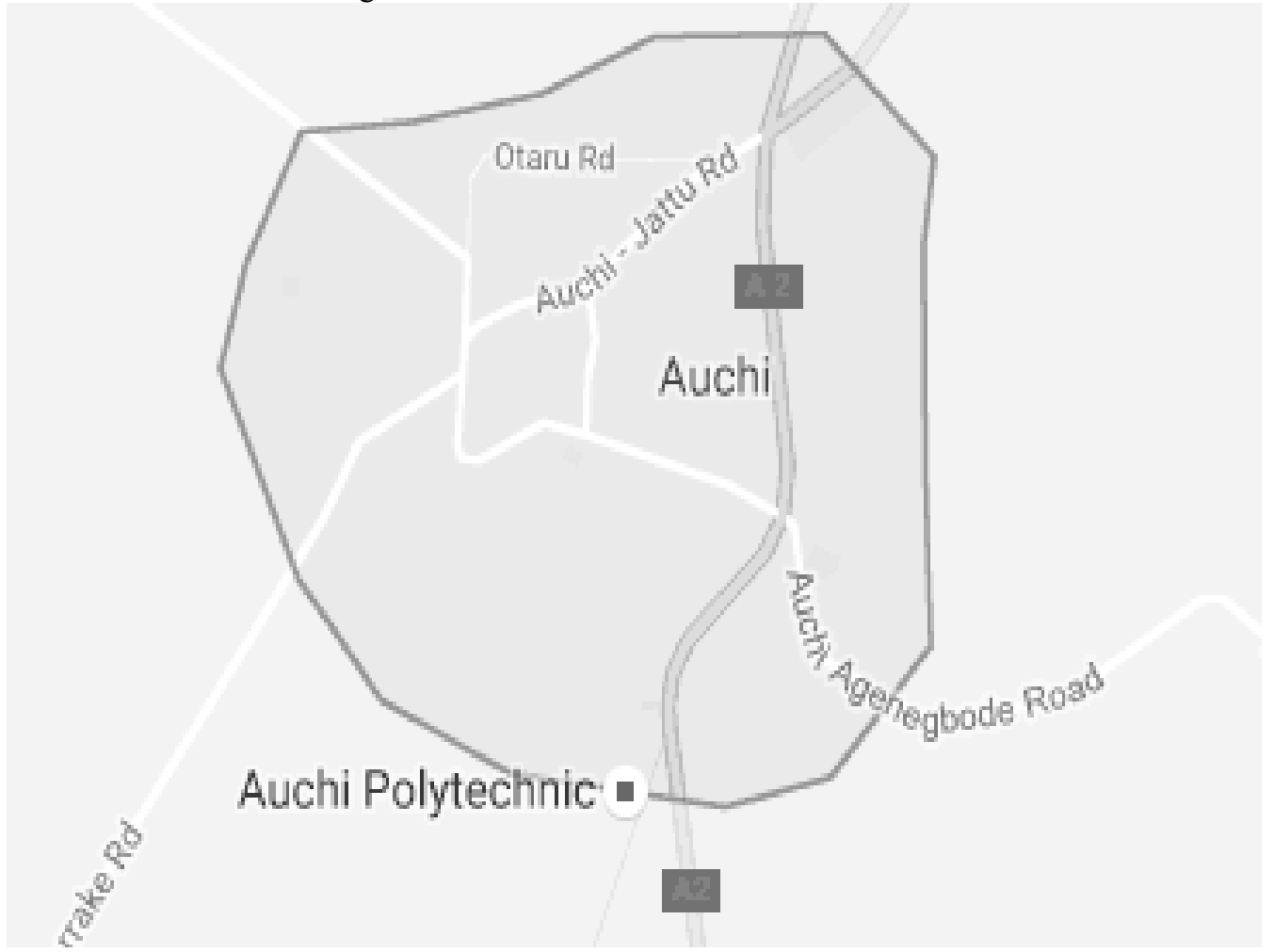

Figure 1: Google map of Auchi Polytechnic and its environs.

\subsection{Design Considerations}

The fabrication of the splash cups and splash board was carried based on the principles of the already existing devices in literature and in the department of Agricultural and Bio-Environmental Engineering Technology Auchi Polytechnic Auchi. 
The following requirements were taken into consideration in the design of the devices:

i. The availability of materials locally to reduce the costs of fabrication and maintenance compared to imported machine;

ii. The strength of materials should be able to withstand the forces acting on the various component parts.

iii. Resistance to rust and corrosion

\subsection{Material Selection}

The materials to be used for the fabrication are listed in table 1, their sizes and quantities are also specified.

Table 1: Materials, Size, Quantity

\begin{tabular}{cccc}
\hline S/N & MATERIALS & SIZE & QUANTITY \\
\hline 1 & Mild steel sheet metal & $1.5 \mathrm{~mm}$ & 1 \\
2 & Hollow pipe & $\varnothing 10 \mathrm{~cm}$ & 1 \\
3 & Muslin cloth (linen) & 3 yards & 3 \\
4 & Recording sheets & & 15 \\
5 & Small take away plastic containers & & 20 \\
6 & Timber & $2 \times 4$ & \\
7 & Ply wood & $1 / 2$ yard & \\
8 & Cellophane bags & & 1 yard \\
9 & Electrode & & 1 pack \\
10 & Cutting disc & & 3 \\
11 & Grinding disc & 3 \\
12 & Paint & 1 cup \\
\hline
\end{tabular}

\subsection{Assembling of Component Parts}

The materials and their various sizes as listed in Table 1 were purchased locally. The sheet metal was cut into the various sizes based on the development in form of a cylinder in the design and welded at one end to form an open end cylinder. The inner pipes were cut from $10 \mathrm{~cm}$ diameter hollow pipe. The splash board was constructed in civil engineering wood workshop following the dimensions in the design session of this write up.

\subsection{Design Calculation}

\subsubsection{Design of Morgan's Splash Cup}

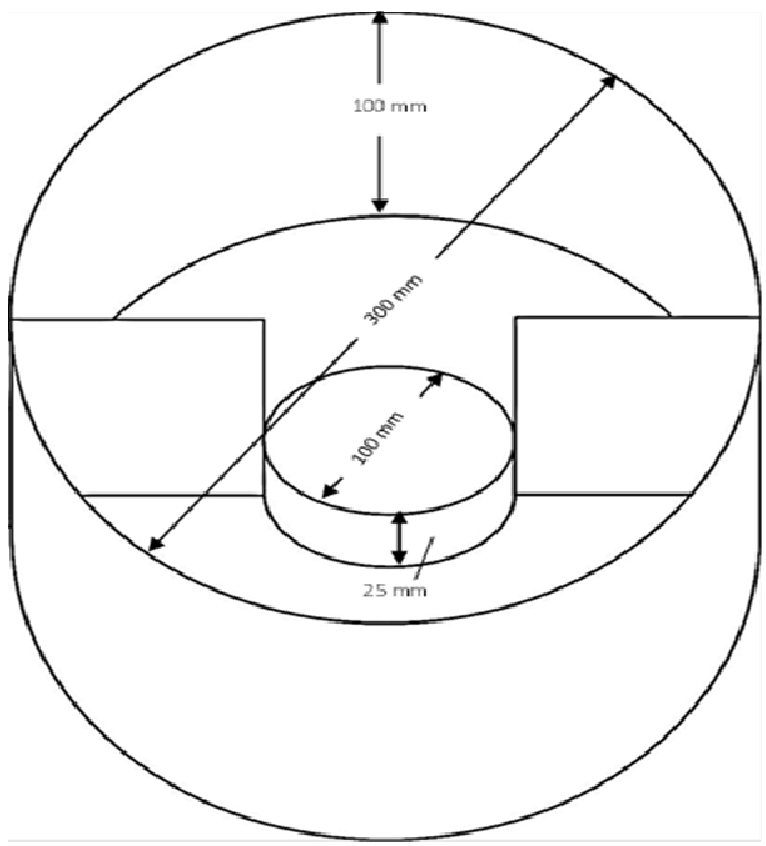

Figure 2: The Morgan's splash cup

(Tameni and Vlek, 2008)

a. The outer cylinder

Height $100 \mathrm{~mm}$, Diameter $300 \mathrm{~mm}$ 


$$
\begin{gathered}
\text { Wherer }=\frac{d}{2}, \quad d=300=\frac{300}{2}=150 \mathrm{~mm} \\
H=100 \mathrm{~mm}, \quad \pi=3.142 \\
\text { Area }(A)=2 \pi r^{2}+h(2 \pi r) \\
=2 \times \pi \times 150^{2}+100(2 \times \pi \times 150) \\
=141,390+94,260 \\
=235,650 \mathrm{~mm}^{2} \\
V=\pi r^{2} h \\
V-3.142 \times 150^{2} \times 100-7,069,500 \mathrm{~mm}^{3}
\end{gathered}
$$

b. The Inner cylinder

Height 110 mm, Diameter 100 mm

$$
\begin{gathered}
\text { Where } r=\frac{d}{2}, \quad d=100=\frac{100}{2}=50 \mathrm{~mm} \\
H=110 \mathrm{~mm}, \quad \pi=3.142 \\
\text { Area }(A)=2 \pi r^{2}+h(2 \pi r) \\
=2 \times \pi \times 50^{2}+110(2 \times \pi \times 50) \\
=15,710+34,562 \\
=50,272 \mathrm{~mm}^{2} \\
V=\pi r^{2} h \\
V-3.142 \times 50^{2} \times 110-864,050 \mathrm{~mm}^{3}
\end{gathered}
$$

c. The flanges

Height 100 mm, length $100 \mathrm{~mm}$

$$
\operatorname{Area}(A)=L \times B
$$

$$
\begin{aligned}
& =100 \times 100 \\
& =10,000 \mathrm{~mm}^{2}
\end{aligned}
$$

2.5.2 Design of Splash Board

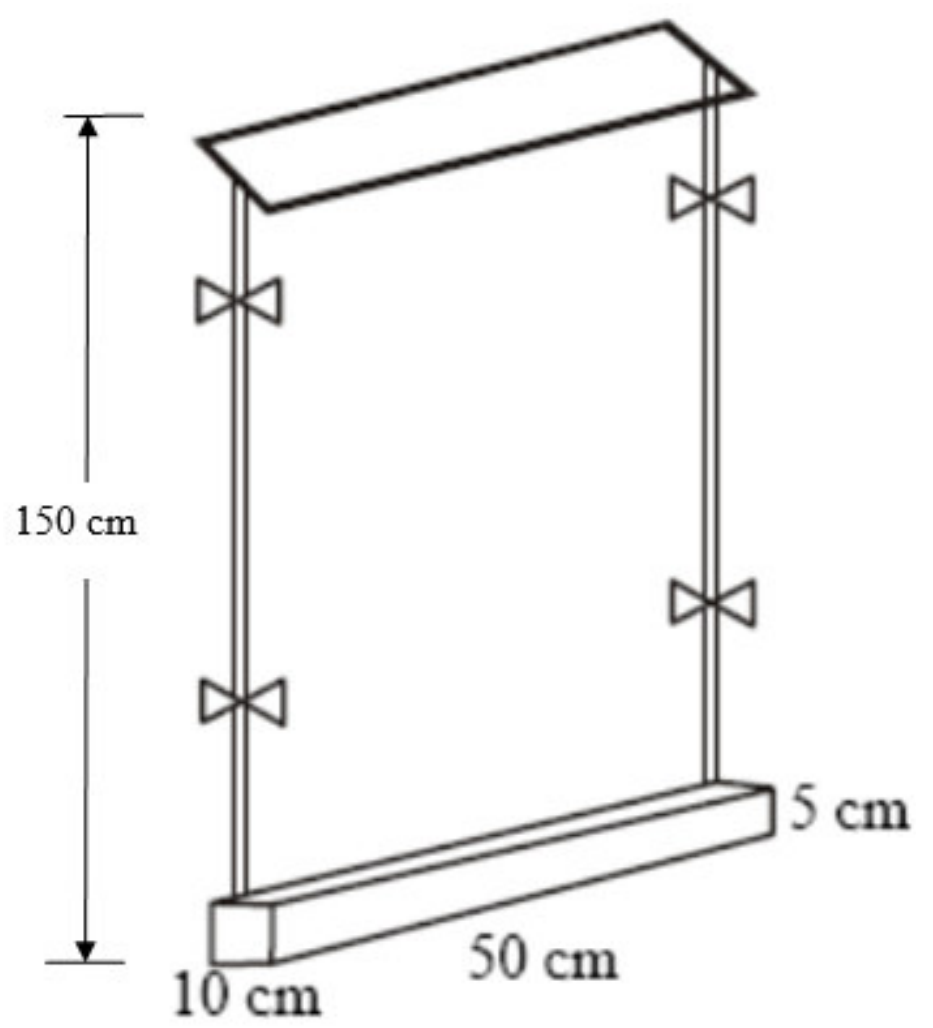

Figure 3: The splash board

(Tameni and Vlek, 2008) 


\subsection{Experimental Design}

Before the experiment was conducted, soil samples was taken to determine the texture of the plots, the experiment to compare splash erosion measuring devices was carried out on three different sites which was labelled as soil A, soil B and soil C respectively site A is behind Agricultural and Bio-Environmental Engineering workshop, site $\mathrm{B}$ is around the meteorological station close to e-learning centre around degree programme block and site $\mathrm{C}$ is close to Polymer Engineering Technology department. The soils were kept bare during the monitoring period by manual removing of the new seedlings.

Rainfall intensity was monitored using a local rain gauge (container and funnel). Kinetic energy was calculated with the help of equation (1) with the values of measured rainfall intensity. The kinetic energy (KE), a widely used indicator of the potential ability of rain to detach soil and splash, is related to I as a logarithmic function (Wishmeier and Smith 1978; Brandt, 1990):

$$
\begin{gathered}
K E\left(\mathrm{~J} \mathrm{~m}^{-2} \mathrm{~mm}^{-1}\right)=210+89 \log 10(\mathrm{I}) \\
I=m m h^{-1}
\end{gathered}
$$

The amount of soil lost due to splash erosion was determined with the help of the following equation.

$$
\mathrm{D}=\begin{aligned}
& M \\
& \mathrm{~A}
\end{aligned}
$$

In this equation:

$\mathrm{D}=$ the amount of soil lost by splashing from unit soil surface $\left(\mathrm{g} \mathrm{m}^{-2}\right)$

Splash amount $(\mathrm{M}, \mathrm{g})=$ the amount of soil splashing from the inner cylinder $(\mathrm{g})$

$\mathrm{A}=$ Area of a circle $\left(\mathrm{m}^{2}\right)(\mathrm{R}=10 \mathrm{~cm})$

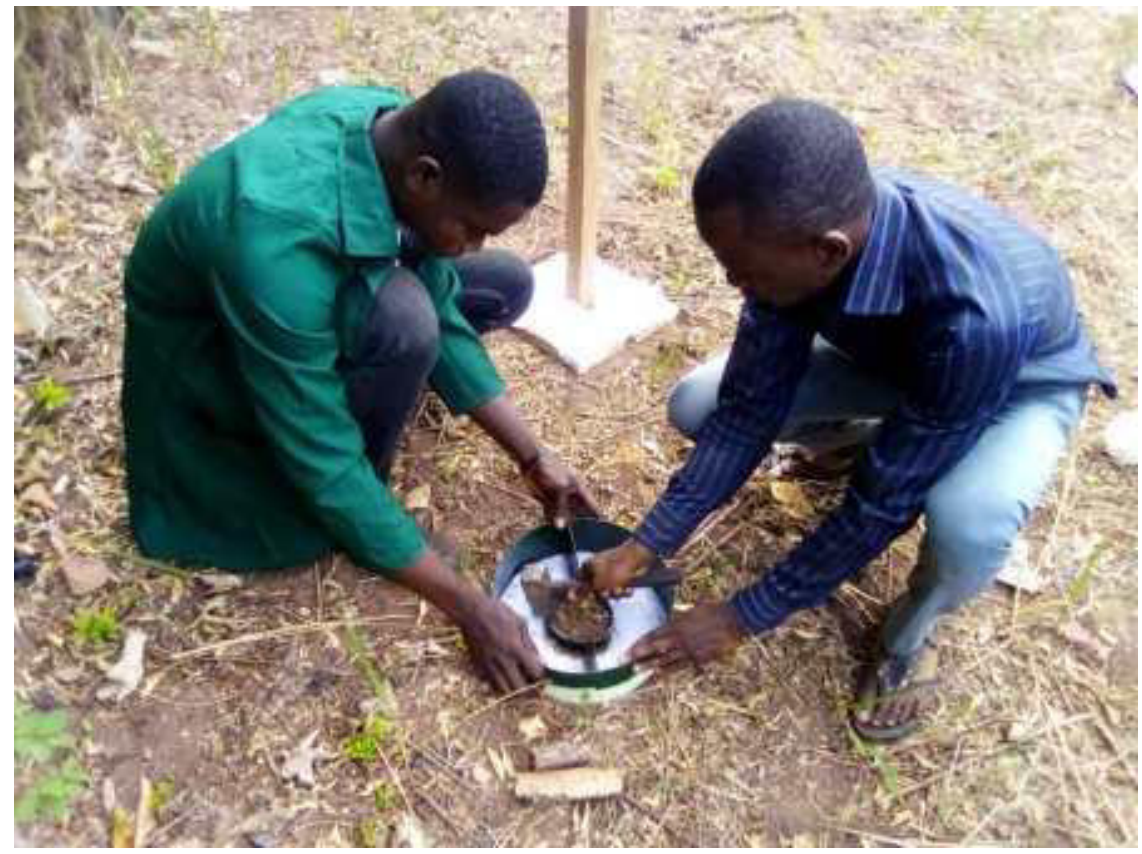

Plate 1: Installation of Morgan's splash cup and splash board in site A

\subsection{Splash Monitoring}

Splash erosion was monitored with devices; Morgan's splash cups (Morgan 1981) and the splash board placed on each plot with three replication of both Morgan cup and splash board on each plot. The rain gauge used to monitor rainfall event was recorded after every rainfall event.

\subsubsection{Morgan Cup}

This simple device consists in a circle with another smaller circle inside in contact with the soil. The inner circle, a rim of $2.5 \mathrm{~cm}$ and $10 \mathrm{~cm}$ in diameter is pushed into the ground until flush with the soil surface. Soil particles splashed from the block of soil isolated in this way accumulate inside the splash cup. To avoid sediment loss, a porous membrane was used between the cups. This allows the water slowly drain from the cups but prevented the sediment from escaping. The outer cup, $30 \mathrm{~cm}$ in diameter and with a $10 \mathrm{~cm}$ high boundary wall catches about 90 percent of the particles detached from the soil in the inner cylinder and excludes a similar percentage of the particles detached from the outside the catching tray.

\subsubsection{Splash Board}

A splash board is a simple device designed to monitor the amount of soil splash, as well as the height of the soil being splashed (Mastura et al., 2006). The board was based on Trudgill's (1983) design with slight 
modifications. The board was $120 \mathrm{~cm}$ high, $10 \mathrm{~cm}$ wide and made of wooden plywood $3 \mathrm{~cm}$ thick which was painted white colour with auto base paint. It was mounted vertically emplacing the lower $20 \mathrm{~cm}$ of the board in the soil so as to achieve stability. At the base of the board was a trough to catch splashed material. After every rainfall event, when the splashed material had been collected, the board was rinsed. A zinc covering $15 \mathrm{~cm}$ in diameter along one face of the wooden board, that is, $30 \mathrm{~cm}$ in total diameter was screwed to the top of the wood. It serves as ceiling cover for the board to prevent the splash on the board to be washed away by the continuing rainfall.

\subsection{Statistical Analysis}

The One-way Analysis of Variance (ANOVA) of the data was carried out Microsoft Excel 2010. The P value is $<0.05$, considered extremely significant.

\subsection{RESULTS AND DISCUSSION}

3.1 Soil Characteristics of the sites

Table 2: Some physical properties of the soils of the experimental fields

\begin{tabular}{lccccccc}
\hline Site & Sand\% & Silt\% & Clay\% & $\begin{array}{c}\text { Bulk density } \\
\mathbf{g} / \mathbf{c m}^{\mathbf{3}}\end{array}$ & $\begin{array}{c}\text { Particle density } \\
\mathbf{g} / \mathbf{c m}^{\mathbf{3}}\end{array}$ & Porosity \% & Soil type \\
\hline A & 70 & 10 & 20 & 1.69 & 2.45 & 31.0 & Loam Soil \\
B & 80 & 10 & 10 & 1.63 & 2.53 & 33.6 & Sand Clay Loam \\
C & 55 & 15 & 30 & 1.54 & 2.59 & 40.5 & Sandy Loam \\
\hline
\end{tabular}

The table above shows that the three sites chosen to carry out this study have soil types ranging from loam, sand clay loam and sandy loam with considerable bulk densities and percentage porosities.

\subsection{Rainstorm Depth and Kinetic Energy}

Table 3 shows the rainfall depth (amount) and the Kinetic Energy (KE) of the rainstorm in the season. The rainstorm depth ranged from 7 to $81 \mathrm{~mm}$ and the computed $\mathrm{KE}$ obtained ranged from 294 to $3233.4 \mathrm{~J} / \mathrm{m}^{2}$. A total of 15 rainfall events were used in the season.

\begin{tabular}{ccc} 
Table 3: Rainstorm depth (amount) and computed Kinetic Energy \\
\hline S/No. & Rainfall Amount (mm) & Kinetic Energy $\left(\mathbf{J} / \mathbf{m}^{\mathbf{2}}\right)$ \\
\hline 1 & 67 & 2653.8 \\
2 & 22 & 790.8 \\
3 & 16 & 542.4 \\
4 & 10 & 294 \\
5 & 11 & 335.4 \\
6 & 50 & 1950 \\
7 & 55 & 2157 \\
8 & 72 & 2860.8 \\
9 & 9 & 252.6 \\
10 & 80 & 3192 \\
11 & 12 & 376.8 \\
12 & 9 & 252.6 \\
13 & 6 & 128.4 \\
14 & 81 & 3233.4 \\
15 & 7 & 169.8 \\
\hline Total & $\mathbf{5 0 7}$ & $\mathbf{1 9 1 8 9 . 8}$ \\
\hline Mean & $\mathbf{3 3 . 8}$ & $\mathbf{1 2 7 9 . 3 2}$ \\
\hline
\end{tabular}

\subsection{Soil splashed for different sites}

Table 4 shows the soil splashed $\left(\mathrm{g} / \mathrm{m}^{2}\right)$ from the three different sites for the rainfall event recorded under the Morgan cup and splash board respectively. It shows that for site A the amount of soil splashed per rainfall event ranged from $0.02 \mathrm{~g} / \mathrm{m}^{2}$ to $4.77 \mathrm{~g} / \mathrm{m}^{2}$ and zero (no splash) to $2.39 \mathrm{~g} / \mathrm{m}^{2}$ for Morgan cup and Splash board device respectively. In site $B$, soil splashed ranged from $0.01 \mathrm{~g} / \mathrm{m}^{2}$ to $1.99 \mathrm{~g} / \mathrm{m}^{2}$ and zero (no splash) to $1.48 \mathrm{~g} / \mathrm{m}^{2}$ for Morgan cup and splash board respectively; While for site C, soil splashed ranged from $0.34 \mathrm{~g} / \mathrm{m}^{2}$ to $6.50 \mathrm{~g} / \mathrm{m}^{2}$ and $0.01 \mathrm{~g} / \mathrm{m}^{2}$ to $4.43 \mathrm{~g} / \mathrm{m}^{2}$ for Morgan cup and splash board devices respectively thus recording the highest splash occurrence. The total soil splashed for the loamy soil field is $52.17 \mathrm{~g} / \mathrm{m}^{2}$ and $28.32 \mathrm{~g} / \mathrm{m}^{2}$ for Morgan cup and splash board devices respectively. For the sandy clay loam field, total soil splashed is $18.24 \mathrm{~g} / \mathrm{m}^{2}$ and 11.28 $\mathrm{g} / \mathrm{m}^{2}$ for Morgan cup and splash board devices respectively; while for the sandy loamy field the soil splashed is $80.16 \mathrm{~g} / \mathrm{m}^{2}$ and $53.76 \mathrm{~g} / \mathrm{m}^{2}$ for Morgan cup and splash board devices respectively.

Table 5 also shows that the soil splashed for Morgan cup was generally higher than that from the splash 
board device. This may be because soil splashed from the inner hollow cylinder is trapped in the outer cylinder in Morgan cup but this is not so for the splash board thus soil splashed could still be blown away by wind action for the splash board device. Also it was generally observed that the higher the Kinetic energy of rainfall the higher the soil detached for both measuring devices (Morgan cup and splash board) across the three sites.

Table 4: Soil splashed for the sites

\begin{tabular}{ccccccc}
\hline & \multicolumn{7}{c}{ Soil splashed $\left(\mathbf{g} / \mathbf{m}^{\mathbf{2}}\right)$} \\
\cline { 2 - 7 } & \multicolumn{2}{c}{ Site A } & \multicolumn{2}{c}{ Site B } & \multicolumn{2}{c}{ Site C } \\
\cline { 2 - 7 } & $\begin{array}{c}\text { Morgan's } \\
\text { cup }\end{array}$ & $\begin{array}{c}\text { Splash } \\
\text { board }\end{array}$ & $\begin{array}{c}\text { Morgan's } \\
\text { cup }\end{array}$ & $\begin{array}{c}\text { Splash } \\
\text { board }\end{array}$ & $\begin{array}{c}\text { Morgan's } \\
\text { cup }\end{array}$ & $\begin{array}{c}\text { Splash } \\
\text { board }\end{array}$ \\
\hline 1 & 4.69 & 2.5 & 1.25 & 0.59 & 6.37 & 4.90 \\
2 & 2.27 & 1.38 & 0.79 & 0.27 & 2.19 & 0.92 \\
3 & 1.17 & 0.76 & 0.53 & 0.43 & 1.65 & 0.83 \\
4 & 0.40 & 0.02 & 0.10 & 0.00 & 0.49 & 0.34 \\
5 & 0.03 & 0.00 & 0.03 & 0.00 & 0.38 & 0.03 \\
6 & 3.61 & 2.87 & 1.32 & 1.00 & 6.50 & 3.76 \\
7 & 3.94 & 2.09 & 1.29 & 1.18 & 6.62 & 4.64 \\
8 & 4.73 & 2.69 & 1.49 & 0.95 & 5.70 & 4.82 \\
9 & 0.37 & 0.03 & 0.09 & 0.00 & 0.44 & 0.26 \\
10 & 4.06 & 2.09 & 1.54 & 0.78 & 6.11 & 4.94 \\
11 & 0.39 & 0.02 & 0.05 & 0.01 & 0.45 & 0.03 \\
12 & 0.08 & 0.00 & 0.03 & 0.00 & 0.38 & 0.13 \\
13 & 0.02 & 0.00 & 0.01 & 0.00 & 0.34 & 0.01 \\
14 & 4.77 & 2.39 & 1.99 & 1.48 & 6.50 & 4.43 \\
15 & 0.05 & 0.01 & 0.03 & 0.00 & 0.39 & 0.03 \\
\hline Total & $\mathbf{3 0 . 5 8}$ & $\mathbf{1 6 . 8 5}$ & $\mathbf{1 0 . 5 4}$ & $\mathbf{6 . 6 9}$ & $\mathbf{4 4 . 5 1}$ & $\mathbf{3 0 . 0 7}$ \\
\hline Mean & $\mathbf{2 . 0 4}$ & $\mathbf{1 . 1 2}$ & $\mathbf{0 . 7 0}$ & $\mathbf{0 . 4 5}$ & $\mathbf{2 . 9 7}$ & $\mathbf{2 . 0 0}$ \\
\hline
\end{tabular}

\section{Kinetic Energy-Soil Splashed Relationship}

Figures 4-6 shows the relationship between kinetic energy and soil splashed from the three sites for the two different devices used to carry out the experiment.

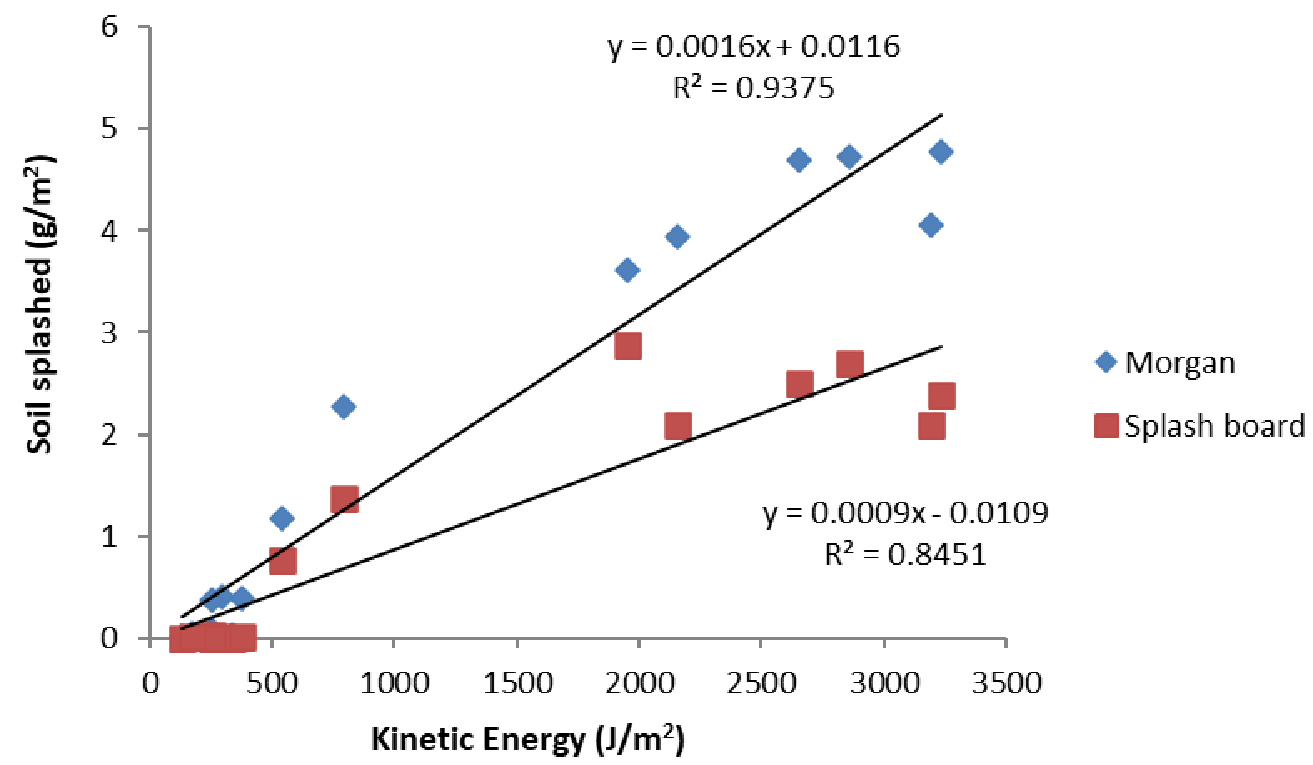

Fig. 4: Soil splash-kinetic energy relationship for Site A for Morgan cup and splash board devices. 


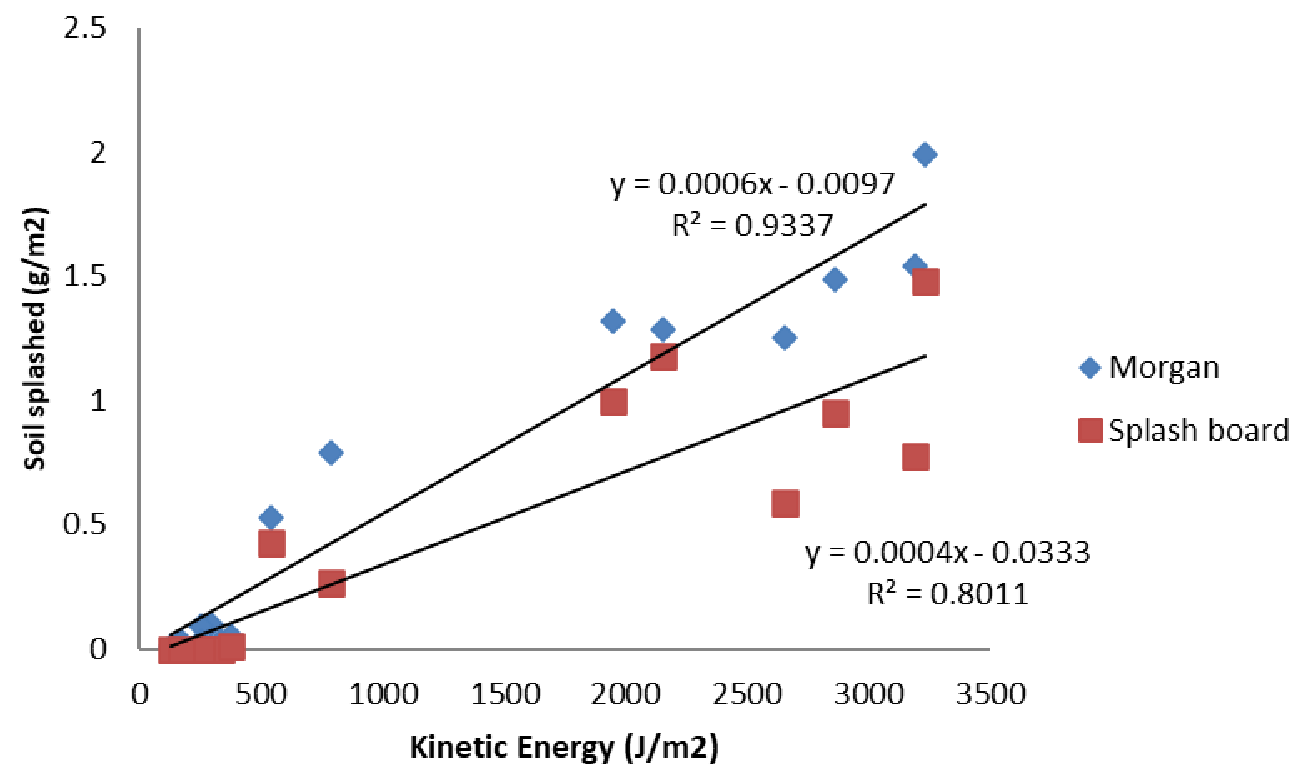

Fig. 5: Soil splash-kinetic energy relationship for Site B for Morgan cup and Splash board.

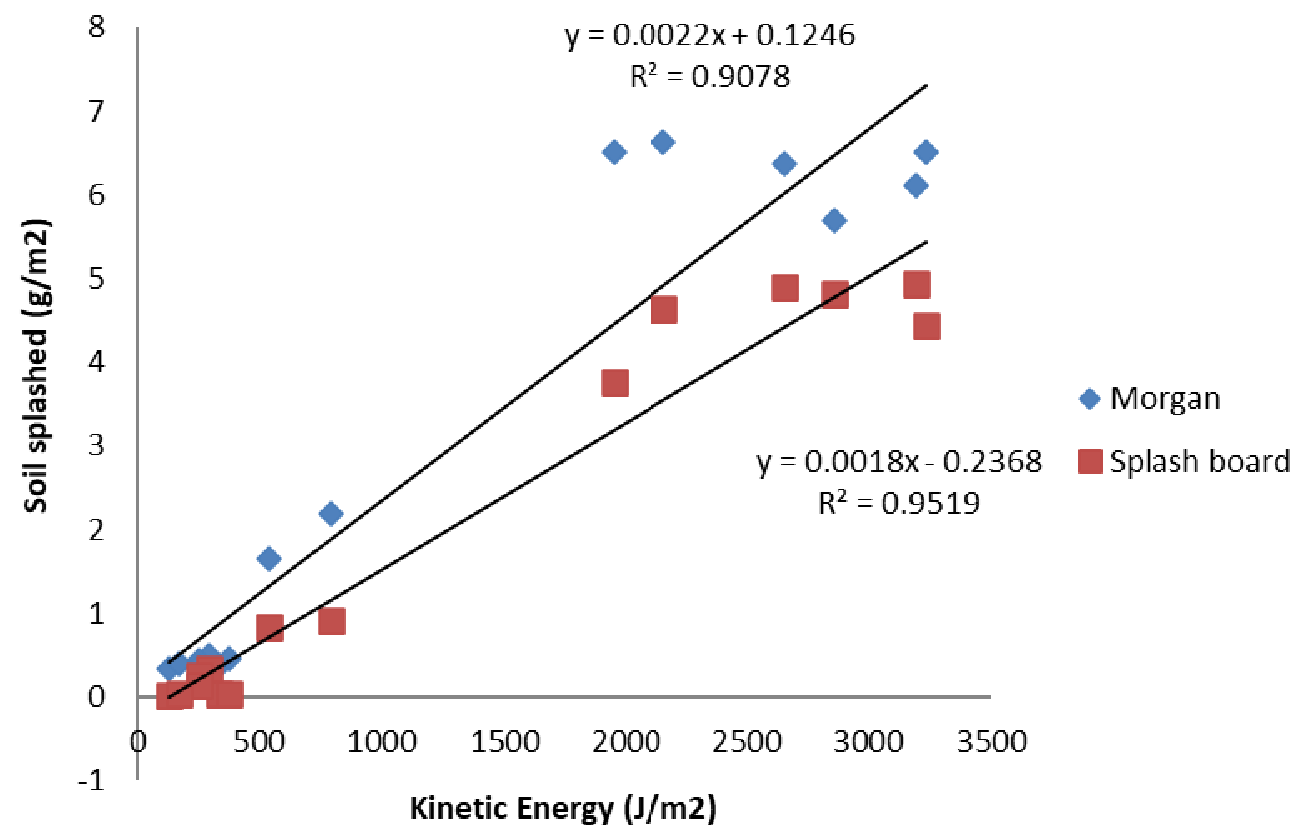

Fig. 6: Soil splash-kinetic energy relationship for Site C for Morgan cup and Splash board.

Figures 4-6 show that there is a linear relationship between kinetic energy and soil splashed in all the sites. All the expressions had a good coefficient of determination $\left(\mathrm{r}^{2}\right)$ as suggested by Morgan (1978).

At the onset of the rainy season, the initial Kinetic energy required to cause soil splash occurrence in the site A was $169.8 \mathrm{~J} / \mathrm{m}^{2}$ for splash device while there was soil splash for all the various kinetic energies computed for Morgan cup device for the loamy field. For the site B field, the initial kinetic energy required for soil splash to occur is $128.4 \mathrm{~J} / \mathrm{m}^{2}$ and $252.6 \mathrm{~J} / \mathrm{m}^{2}$ for Morgan cup and splash devices respectively. Also, for the site $\mathrm{C}$ the initial kinetic energy which causes splash to occur is $87 \mathrm{~J} / \mathrm{m}^{2}$ and $128.4 \mathrm{~J} / \mathrm{m}^{2}$ for Morgan cup and splash board respectively. Lower kinetic energy could also cause soil splash as the rainy season went on. This is because the field was kept bare throughout the experiment and constant exposure of the top soil to continuous rainfall increases its susceptibility to soil splash. This is mostly noticed especially when a small rainfall was preceded by a heavy rainfall. The heavy rainfall would have weakened the soil particles, thus, making it easy for small rainfall drop afterwards to cause splash detachment. 
Splash Comparison for the three Sites as measured by Morgan cup and Splash board devices

The T-test was used to compare the soil splashed as measured by Morgan cup and Splash board devices for each site. This was found to be significant at the 0.05 level of significance.

Table $5-7$ shows the T-test for sites A, B and $\mathrm{C}$ respectively.

Table 5: T-test result for site A

\begin{tabular}{lrr}
\hline & Variable 1 & Variable 2 \\
\hline Mean & 2.038666667 & 1.123333333 \\
Variance & 4.057126667 & 1.409066667 \\
Observations & 15 & 15 \\
Pearson Correlation & 0.974717882 & \\
Hypothesized Mean Difference & 0 & \\
df & 14 & \\
t Stat & 3.950835516 & \\
t Critical two-tail & 2.144786688 & \\
\hline
\end{tabular}

Table 6: T-test result for site B

\begin{tabular}{lrr}
\hline & Variable 1 & Variable 2 \\
\hline Mean & 0.702666667 & 0.446 \\
Variance & 0.503078095 & 0.265425714 \\
Observations & 15 & 15 \\
Pearson Correlation & 0.95438028 & \\
Hypothesized Mean Difference & 0 & \\
df & 14 & \\
t Stat & 3.730412003 & \\
t Critical two-tail & 2.144786688 & \\
\hline
\end{tabular}

Table 7: T-test result for site $\mathrm{C}$

\begin{tabular}{lrr}
\hline & Variable 1 & Variable 2 \\
\hline Mean & 2.967333333 & 2.004666667 \\
Variance & 8.239906667 & 4.885426667 \\
Observations & 15 & 15 \\
Pearson Correlation & 0.98337335 & \\
Hypothesized Mean Difference & 0 & \\
df & 14 & \\
t Stat & 4.635646826 & \\
t Critical two-tail & 2.144786688 & \\
\hline
\end{tabular}

In all the t-tests, since the tstat is higher than the tcritical, there is no significant difference between the results of soil splashed from the Morgan's splash cup and the splash boards.

\subsection{CONCLUSION}

Having achieved the objectives of this study, the following conclusion is made:

1. Soil types ranged from loam, sand clay loam and sandy loam with considerable bulk densities and percentage porosities.

2. The rainstorm depth ranged from 7 to $81 \mathrm{~mm}$ and the computed K.E obtained ranged from 294 to $3233.4 \mathrm{~J} / \mathrm{m}^{2}$. A total of 15 rainfall events were used in the season.

3. For site $A$ the amount of soil splashed per rainfall event ranged from $0.02 \mathrm{~g} / \mathrm{m}^{2}$ to $4.77 \mathrm{~g} / \mathrm{m}^{2}$ and zero (no splash) to $2.39 \mathrm{~g} / \mathrm{m}^{2}$ for Morgan cup and Splash board device respectively.

4. In site $B$, soil splashed ranged from $0.01 \mathrm{~g} / \mathrm{m}^{2}$ to $1.99 \mathrm{~g} / \mathrm{m}^{2}$ and zero (no splash) to $1.48 \mathrm{~g} / \mathrm{m}^{2}$ for Morgan cup and splash board respectively;

5. While for site $C$, soil splashed ranged from $0.34 \mathrm{~g} / \mathrm{m}^{2}$ to $6.50 \mathrm{~g} / \mathrm{m}^{2}$ and $0.01 \mathrm{~g} / \mathrm{m}^{2}$ to $4.43 \mathrm{~g} / \mathrm{m}^{2}$ for Morgan cup and splash board devices respectively thus recording the highest splash occurrence.

6. The T-test was used to compare the soil splashed as measured by Morgan cup and Splash board devices for each site. This was found to be significant at the 0.05 level of significance. Table $4.4-4.6$ shows the T-test for sites $\mathrm{A}, \mathrm{B}$ and $\mathrm{C}$ respectively.

\subsection{RECOMMENDATIONS}

The following recommendations are made from this study:

1. Studies of splash erosion on cultivated land should be made to determine the effect of cultivation on the 
soil in the area.

2. Each field should have its own rain gauge to determine its own rainstorm event especially if the fields are very far from each other.

\section{REFERENCES}

Daba, S.; Rieger, W.; Strauss, P. (2003) Assessment of gully erosion in eastern Ethiopia using photogrammetric techniques. CATENA 50(2-4) pp. 273-291

Fan R. and Li Z., (1993). Rainsplash and sediment transport model on the slope. Journal of Hydraulic Engineering, (6): 24-29.

Gebreyohannis Gebrehiwot, S.; Taye, A.; Bishop, K. (2009) Forest Cover and Stream Flow in a Headwater of the Blue Nile: Complementing Observational Data Analysis with Community Perception. Ambio 39(4) pp. 284-294

Morgan R. P. C.(2005). Soil erosion and conservation. Third Edition Book. National Soil Resources Institute, Cranfield University. Pg 1-316.

Poesen, J. (2011) Challenges in gully erosion research. Landform Analysis 17 pp. 5-9

Salama, R.B.; Otto, C.J.; Fitzpatrick, R.W. (2008) Contributions of Groundwater Conditions to Soil and Water Salinization. Hydrogeology Journal 7(1) pp. 46-64

Tamene, L.; Vleck, P.L.G. (2007) Assessing the Potential of Changing Land Use for Reducing Soil Erosion and Sediment Yield of Catchments: a case study in the highlands of Northern Ethiopia. Soil Use and Management 23 pp. 82-91

Vogt, J.V.; Safriel, U.; Maltitz, G. von; Sokona, Y.; Zougmore, R.; Bastin, G.; Hill, J. (2011) Monitoring and Assessment of Land Degradations and Desertification: Towards New Conceptual and Integrated Approaches. Land Degradation and Development 22 pp. 150-165

Wikipedia (2019). Free online dictionary. Accessed 04/11/2019 